University of St. Thomas, Minnesota

UST Research Online

Spring 2018

\title{
"The Limits of the Imaginable": Women Writers' Networks during the Long Nineteenth Century
}

Andrea Jean Stewart

University of St. Thomas, Minnesota

Follow this and additional works at: https://ir.stthomas.edu/cas_engl_mat

Part of the English Language and Literature Commons

\section{Recommended Citation}

Stewart, Andrea Jean, "'The Limits of the Imaginable": Women Writers' Networks during the Long Nineteenth Century" (2018). English Master's Essays. 8.

https://ir.stthomas.edu/cas_engl_mat/8

This Essay is brought to you for free and open access by the English at UST Research Online. It has been accepted for inclusion in English Master's Essays by an authorized administrator of UST Research Online. For more information, please contact asle4660@stthomas.edu. 
"The Limits of the Imaginable": Women Writers' Networks during the Long Nineteenth Century

by

\section{Andrea Jean Stewart}

A master's essay submitted to the faculty of the Graduate program in English in partial fulfillment of the requirements for the degree

Master of Arts in English

University of St. Thomas

Saint Paul, Minnesota

May 2018 


\section{Acknowledgements}

First and foremost, I would like to thank the Cambridge University Press staff and editorial team for allowing me access to the Orlando Project digital database and for their permission to use the data I mined from the archive in this essay. I'd also like to say thank you to my review committee, Dr. Amy Muse and Dr. Paul Fyfe, for their wonderful advice and the number of sources they suggested and supplied to supplement my research.

I'd also like to especially thank my advisor, Dr. Alexis Easley. The support and encouragement you've given me (as well as the multitude of job opportunities, research experiences, networking connections, etc.) over the past four years has made my time in the program so meaningful and rewarding. I' $m$ a better scholar, editor, and writer because of the time I've spent with you and I truly appreciate your guidance and mentorship more than I can say.

Finally, I'd like to say thank you to my family and friends. To my Mom and Dad, you are the best and most supportive parents I could ever ask for. To my husband Chris, thank you for all the encouragement you've given me and for understanding when I (frequently) get lost in my reading and research. To my extended family and friends, thank you all for every time you asked about my studies and patiently listened to my extremely lengthy answers-your interest and attention sustained me through many difficult scholarly moments. And finally thank you to Mercedes Sheldon, without whom this (and many other essays) could not have been researched, written, or edited properly. I could never have made it this far without all of you! 


\begin{abstract}
The rapid rise of the digital humanities over the past decade has transformed literary study, helping scholars to discern broader patterns in print culture and media history. Engaging with methodologies such as data mining, macroanalysis, and network analysis, my Master's Essay utilizes these computational analytics approaches in order to address longstanding critical questions in women's literary history-in particular, how might these tools help us understand the crucial rise of women's networks during the long nineteenth century. To what extent were women's relationships with fellow female authors important to their success in a male-dominated publishing marketplace and what new insights are gained from viewing these relationships on a macro-analytic level, rather than simply viewing the individual network or the network of "important" or "canonical" writers associated with a particular literary period or movement?

In taking a distant approach without privileging canonical authors over others, the macronetwork I generated from mining bio-data of nearly 700 women writers becomes a fluid model from which new trails of scholarship can be mapped rather than a stagnant source of evidentiary support for pre-existing arguments. Utilizing networking software to track details of women's interactions with one another my essay reveals several surprising who functioned as crucial nodes in communities of women writers during the long nineteenth century-Joanna Baillie, Geraldine Jewsbury, and Margaret "Storm" Jameson-and offers an analysis of why this high connectivity has not translated into canonicity.

Of course, any database of women writers obscures as much as it reveals about women's experience as participants in gendered publication networks, and my essay closes with analysis and acknowledgement of the archival absences, gaps, and biases of human politics embedded in the data in- and exclusion process encoded within the construction of the Cambridge University's Orlando Project digital database, from which my information was mined.
\end{abstract}


"The Limits of the Imaginable": Women Writers' Networks during the Long Nineteenth Century

\section{ANDREA STEWART}

The rapid rise of the digital humanities over the past decade has transformed literary study, helping us to discern broader patterns in print culture and media history. Franco Moretti's and Matthew Jockers's respective introductions to distant reading and macroanalysis have fundamentally altered the way that many scholars now approach literary research. ${ }^{1}$ In light of their impact on the digital humanities field, I wondered how these methodologies might help us to address longstanding critical questions in women's literary history. In particular, how might they help us understand women's social and literary networks during the long nineteenth century? To what extent were women's relationships with fellow women writers-their networks of connectivity-important to their success in a male-dominated publishing marketplace? If, as some researchers have suggested, women formed "alternative networks" to the masculine clubs, universities, and editorial establishments that informed patriarchal print culture, how might we begin to understand these relationships on a broad scale? ${ }^{2}$ As Joanne Shattock observes, "Women's literary networks were less obvious and less public" than men's and are therefore more difficult for current scholars to trace and assemble. ${ }^{3}$ To date, studies of individual writers have revealed the ways in which women's clubs, salons, and other social relationships informed their engagement with popular print culture. ${ }^{4}$ Of course, women also connected and collaborated with each other through editing, reviewing, and other professional roles. To understand the ways women functioned within a complex network of private and professional relationships, however, it is important to go beyond a single case study approach, which often has the effect of rounding up the usual suspects-canonical women writers-and interpreting their experiences as representative of the field. 
Using large-scale data analytics, scholars have begun the process of revealing broader patterns of connectivity in the history of women's writing. For example, Marianne Van Remoortel's grant-funded project, Agents of Change: Women Editors and Socio-Cultural Transformation in Europe, aims to highlight "the impact of women editors on public debate" by "[mapping] the transnational networks of intellectual exchange in which women editors participated. $"$ Likewise, Alison Booth, curator of the web archive Collective Biographies of Women, encourages users to rediscover the relationships between "thousands of women of all kinds and eras" and to investigate "women's life narratives in depth as well as en masse."6 Following in these scholars' footsteps, my own work employs macroanalysis to map women's networks of connectivity in popular print culture during the long nineteenth century. My generated macro-network graph reveals how certain women writers functioned as highly visible and centrally located "nodes" within these publishing networks and how these heretofore overlooked writers have been surprisingly influential in the history of women's authorship. I explore how studying women's social and professional networks on a broad scale can lead to a deeper understanding of the various ways in which they connected with each other and with print culture during their careers and how this might be correlated with their canonical status, past and present. I also investigate the extent to which the structural nature of women writers' connections with each other shifted over time.

Engaging with various digital humanities methodologies such as data mining, distant reading, and network analysis, I build on the work of scholars such as Laurel Brake, Nathan K. Hensley, Natalie Houston, and Joanne Shattock. ${ }^{7}$ In so doing, my essay investigates what new insights can be gained from viewing women's relationships with each other on a comprehensive scale rather than simply viewing the individual network or the network of "important" or 
"canonical" writers associated with a particular literary period or movement. I also speculate on how a study of networked connectivity might challenge our understanding of which authors were most highly connected, and thus presumably most influential, in the accounts of women's writing. Literary scholarship has historically tended to focus on a small canon of writers, leaving their "rivals," as Moretti terms them, to become part of the "great unread." ${ }^{8}$ Following the work of John Burrows, I hope to bring to light those writers who have "escaped our attention because of [the] sheer multitude" of existent women within the publishing industry in the nineteenth century and to discover why some writers succeeded more than others in terms of creating connections with fellow female authors and in achieving canonical status over the long term. ${ }^{9}$

While outlining his introduction to network visualization, J. Stephen Murphy surmises that "any medium that groups writers together has the potential to turn writers into conduits through which other writers can be discovered." 10 Indeed, my macroanalytic approach to network analysis aims to increase our appreciation of the highly influential, hyper-connected writers who often operated behind the scenes of print culture, as it were. In the process, I hope to raise fresh questions about how we understand women's literary history. How did women's personal and professional relationships intersect during the long nineteenth century? How did women writers parlay these connections into different kinds of writing and editorial work within print culture? Can a macroanalytic approach to data visualization change the way we view writers" "influence or importance" within literary history? Of course, any visualization of women's literary and social networks is necessarily a partial one. I conclude with a brief reflection on the gaps and silences encoded in the Orlando Project digital archive, as well as some thoughts on how scholars might engage with data mining, network analysis and visualization, and issues of canonicity in the continually evolving field of digital humanities. 


\section{Methodology}

In their quantitative study of modernist periodicals and the connections among their reviewers and contributors, J. Stephen Murphy and Mark Gaipa define the term "network" as "a structure of relationships among entities," and Friedrich Kittler likewise delineates a network as "a structure, the technic whereby cultural exchange takes place." 11 However, invoking the notion of "structure" when referring to relationships suggests a state of static kinesis and rigidity. As Nathan K. Hensley cautions, there is an inherent danger that our data analysis techniques do not create anything new but merely function as tools for "re-circulating of existing content" and reinforcing what we already know about pre-established relationships between writers within the publishing industry. ${ }^{12}$ It is perhaps more useful to conceive of networks as "informal, open, multiple, competing, and dynamic" systems, as Simon Potter proposes, or as an ever-expanding organism within which nuclei form through temporal and contextual bonds. ${ }^{13}$

As Laurel Brake notes, most studies of literary networks have tended to focus on particular individuals or particular political, social, religious, and publishing groups. By taking a distant approach that incorporates nearly 700 writers, this study proposes the notion of the network as a fluid model from which new trails of scholarship can be mapped rather than a stagnant structure of evidentiary support for pre-existing arguments. A distant reading approach, Matthew Jockers argues, draws "attention to general trends and missed patterns" that must be explored "in detail and [accounted] for with new theories." 14 After all, "the study of literature should be approached not simply as an examination of seminal works but as an examination of an aggregated ecosystem or economy of texts." 15 To this I would add that the study of networks should be approached not simply as an examination of seminal authors but as an examination of an aggregated ecosystem or economy of writers. 
To explore this broader economy, I focus on a much larger sample of women writers than has typically been studied in existing scholarship on women's networks. In so doing, I aim to provide a broader understanding the nineteenth-century woman writer through an examination of contextual biographical and connectivity trends within broader networks of association. Of course, I realize that even in studying the connectivity data of nearly 700 British women writers, I am still working with a small fraction of the large number of women who lived and wrote during the long nineteenth century. Yet my approach goes a long way towards expanding our understanding beyond the narrow set of authors usually studied in in women's history (i.e., Jane Austen, George Eliot, and Virginia Woolf —all of whom are included within my data set even though they are not the focus of this essay). By focusing on a broad sample of women working in the long nineteenth century, I also aim to dislodge assumptions about women's authorship associated with defined literary phases (i.e., Romanticism, Victorianism, and Modernism), which artificially categorize and contextualize women writers according to predetermined assumptions about history, gender, culture, and literary "periods" within the publishing marketplace. As Rita Felski points out, scholars must fight against lazy usage of literary periodization as a shorthand for the specific relationships informing textual production. "History is not a box," she warns, and thus we should not view authors or texts "only as cultural symptoms of their own moment."17

In order to understand women's networks from a macroanalytic perspective, I mined biodata from Cambridge University Press's Orlando Project: Women's Writings in the British Isles from the Beginnings to the Present to produce a spreadsheet that tabulated the personal and professional connections between 684 British women writers of the long nineteenth century catalogued in the database. I selected the particular writers included in this study from the total 
of 1,325 entries on the Orlando site based on two criteria: first, they must have been born or to have died during the nineteenth century, and second, each must have at least one signed publication. ${ }^{18}$ In order to determine each woman writer's connections, I pored through the biographical tabs for each author, noting the names of other women writers that appeared in these narratives; I then cross-referenced these names with the already formulated connections list found under the "Friends, Associates" and "Family" sections, paying special attention to any discrepancies I found between the two-a topic I will revisit in a later section of this essay. The range of connections between writers incorporated into these biographies, as well as into my analysis, included social affiliations such as friendships, familial relationships, and social/political/literary memberships, as well as professional connections such as co-authorship, editor-contributor relations, and the bonds between reviewers and the authors whose works they reviewed. I included any connections between women writers noted in Orlando, no matter how small (e.g., the exchange of just one letter) or how large (e.g., a lifelong friendship). This way I ensured that I would not overlook small but significant connections between the writers in my sample. I then entered the names from my spreadsheet into the open-access software program Gephi to create a visualization that displayed each woman writer's connection to the others.

For each of the women writers listed in my study, I first entered fundamental biographical details from the Orlando Project database into an Excel spreadsheet in order to create a basic biographical outline for each writer that could be expressed in shorthand numeric code and then translated into a visualization. Next, I listed each writer's connections with other women writers as noted in their biographical profile in the digital archive. As I did so, I realized I would need to make qualitative decisions about what I felt constituted a "connection" between authors. Though previous studies have often elected to analyze only the professional 
relationships between authors (i.e., their editing or writing collaborations), I chose to include every possible known connection linking one writer to another-social, political, familial, or otherwise. ${ }^{19}$ Like Bruno Latour, I operated according to the belief that every activity can "be related to and explained by the same social aggregates behind all of them." ${ }^{20}$ In other words, all activities, or the means through which connections are formed and measured, are meaningfully "linked in a way that does produce a society." 21 Social connections between writers, in particular, must be taken into account since they afforded women alternative routes for entering the literary field.

After entering the aggregated data into the free software program Gephi, I produced a visualization of the complex range of connections between the writers in my study (figure 1). In this graph, each node represents a single woman writer, and each edge indicates a connection between two nodes (or two writers). Rather than using relationally weighted edges, which would require me to assign each relationship an arbitrary value of relative significance, I instead selected a visual representation of each connection as being either one-sided or reciprocal. In my graph, a yellow arrow originates at the node for which a one-way connection is formed: for instance, if one author reviewed another but the two writers had no other apparent connection, I marked it as a one-way association originating with the reviewer and the arrow pointing towards the reviewee. For reciprocal connections, such as familial or social relationships, I used a blue double-pointed arrow as the visual link between the two authors. By displaying these seemingly simplistic categorizations of connections between authors, I wanted to highlight the ways in which women's network formations shifted over the years. In early decades of the century reciprocal relationships were most prevalent, showcasing the alternative ways women entered "into the male-dominated" literary marketplace through connections with other women writers 
and how this changed over the course of the century as women writers became more accepted and embedded within the publishing industry. ${ }^{22} \mathrm{I}$ was also interested in developing metrics for measuring the idea of influence. I noted which writers had reciprocal relationships that might indicate influence over one another's writing or career choices and which women were engaged in the one-way relationships often associated with reviewing and retrospective writingcontributing to the important work of documenting women's literary history.

In a network visualization, a node derives its "authority," Murphy and Gaipa inform us, "roughly based on how many other nodes...[it] is linked to." 23 Nodes with numerous convergent edges appear larger than less-connected ones and are color-coded to reflect their higher "authority." As we can see in Figure 1, hyper-connected writers Virginia Woolf and Harriet Martineau are represented by red-colored nodes, while writers with fewer associations are represented by a slightly cooler shade of orange. This pattern repeats through lessening degrees of connectivity and nodal sizes, ending with purple-colored points representing writers generally detached from the main groupings of other female authors (those with few or no connections). Thus, Gephi identifies and accordingly maps network "hotspots"--dense clusters of connectivity focused around particular authorial nodes. We can see that Woolf's and Martineau's relationships span across the graph both spatially and temporally, indicating their high level of connection with writers from a multitude of micro-networks and their tendency to make reference, through retrospective writings, to authors of earlier time periods. Because Woolf and Martineau were highly connected in print culture-reviewing, critiquing, editing, and, in Woolf's case, running a printing press-it is easy to see why they commanded such network authority. Though they belonged to different generations, both Woolf and Martineau had a retrospective trans-temporal tendency in their writing to reflect on past women writers through 
reviews, biographies, and other forms of historical writing, multiplying the number of their associations and thus surpassing many of their peers in connectivity.

Besides Woolf and Martineau, other "hotspots" revealed by my network visualization were more surprising. In the next section of this essay, I focus on three non-canonical authors that emerged as particularly important nodes in my network analysis: Joanna Baillie (17621851), Geraldine Jewsbury (1812-80), and Margaret "Storm" Jameson (1891-1986). I decided to focus on these women because their lives and work are less visible than those of writers like Woolf and Martineau, whose careers and networks have been studied at length and whose canonical status is an accepted commonplace in feminist scholarship. Baillie, Jewsbury, and Jameson were among the most highly connected writers of their respective generations, as we can see both from their central positions within the macro-network as well as from the weight and color of their representative nodes (see figure 1). It could even be supposed, based on this data visualization, that they functioned as the nuclei of distinct, clustered micro-networks around which other nodes seem to have positioned themselves. It is interesting to note that in all three cases high connectivity did not, it seems, translate into canonicity. Their texts are rarely taught in college classrooms or included in anthologies of women's literature. ${ }^{24}$ It is my hope that my own digital humanities project can help to recover and reclaim the work of these writers, which often took place behind the scenes through reviewing, editing, participating in writers' groups, and engaging in various forms of nineteenth-century social networking. While this activity may not have ensured their lasting presence in the literary canon, it nonetheless was influential in the history and production of women's writing during the long nineteenth century.

Until this point, my essay has made an argument for a macroanalytic approach to the study of women writers' history and biography. In the next section, I address the lives and 
network structures of three individual writers; however, I would like to emphasize the difference in my approach to these case studies. Rather than taking an already well-known writer and producing a network of known (or heretofore undiscovered) associates or mapping the interconnectivity of a group of writers who were part of the same literary circle or wrote for a particular periodical, I discovered the objects of my case studies and their subsequence importance in an unplanned way arising organically from my production of a macro-network of women writers, rather than out of a predetermined notion of their significance. By using macroanalysis as the entry point to the study of women's connectivity I effectively reverseengineered the individual case study from a larger set of aggregated data, rather than utilizing the traditional case-study first entry point into network analysis and women's literary studies. Utilizing macroanalytic methods, I was not only able to "discover" these women writers for myself (as I had not previously encountered their names in my own scholarship) but was also able to discern how surprisingly connected and central they were to the formation of women writer's networks in the long nineteenth century. In the following sections I take a biographical approach to three nodes in my visualization to explore just how they came to be so connected, and thus so seemingly influential, in print culture.

\section{Joanna Baillie (1762-1851)}

During the latter half of the eighteenth century, when Joanna Baillie was coming of age as a writer, the literary marketplace became increasingly female dominated. Upper-class women readers had leisure time on their hands, and the industry responded with a flood of novels catering to what Ian Watt terms an "easy vicarious indulgence in sentiment and romance.",25 Baillie's own literary aspirations took root during her time at a boarding school in Glasgow, where she developed a fierce appreciation for reading, especially Scottish poetry. At the age of 
twenty-one, after the death of her father, she accompanied her mother and sister to London where they kept house for Baillie's brother. This was a fortuitous move since it was there that her aunt, Anne Home Hunter (a published poet of small renown), introduced her to literary society.

She regularly took part in her aunt's weekly literary salon, which included attendees such as Anna Laetitia Barbauld, Frances Burney, and Elizabeth Montagu. Encouraged by her aunt's example and the other writers who moved in her circle, Baillie published her first volume of poetry in 1790, Poems: Wherein It Is Attempted to Describe Certain Views of Nature and of Rustic Manners.

Positive reviews of her work appeared in periodicals such as the Monthly Review and the Eclectic Magazine, one, for example, calling her poems "true and lively pictures of nature."26 This affirmative reception gave Baillie confidence to start working in a new genre: drama. She began in small increments, writing introductions and epilogues for friends' productions before eventually moving into producing complete plays of her own through the end of the period. At the turn of the eighteenth century, from 1798 to 1812, Baillie wrote and published three texts that, when later collected, would comprise her most successful work to date-a series of verse dramas creatively entitled Plays on the Passions. After the book of the first play appeared under the name of "Anonymous," London was abuzz with speculation on the author's identity, with most assuming male authorship until Baillie chose to reveal her identity in 1800 . Though the book version of the plays received mixed critical reviews, the successful staging of the plays themselves - produced on Drury Lane with John Philip Kemble and Sarah Siddons in leading roles-led Baillie to "fame almost without parallel," as Harriet Martineau later wrote. She was a dramatist "second only to Shakespeare" in both talent and fame. ${ }^{27}$ 
When examining Baillie's relationships with other women writers on a micro-level (figure 2), it becomes immediately apparent that she enjoyed reciprocal (blue-coded) relationships with most of the authors in her network. A close examination of her biography reveals that these relationships were initiated and maintained through mutual correspondence, social encounters at her aunt's literary salon, and collaborations with fellow artists in the theatrical world. ${ }^{28}$ Unlike the hyper-connected women who emerged later in the century, her relationships with fellow women writers were less likely to be the one-way encounters enabled by professional opportunities in the literary marketplace (e.g., through book reviews). Her hyperconnectivity is of course also attributable to her decision to work primarily as a dramatist rather than as a poet or novelist. Writing for the stage necessitated in-person connections with actors, directors, and other collaborators, some of whom also worked in the publishing industry. For example, the Duchess of Devonshire, Georgiana Cavendish, wrote an epilogue to one of Baillie's earlier productions, De Montfort. Baillie collaborated with Felicia Hemans to secure actors for their shows on numerous occasions and she frequently attended and reviewed Jane Porter's plays of the period. Later, Baillie's work as the editor of a little-known collection of Scottish poetry, $A$ Collection of Poems, Chiefly Manuscript, and From Living Authors, published in April 1823, also afforded her an opportunity to develop both one- and two-way connections to the authors included in the volume. ${ }^{29}$

Simon Potter notes that the networks of late eighteenth- and early nineteenth-century women writers tended to be "only loosely structured" based on personal connections and were often characterized by a "tendency toward homogeneity" owing to the fact that they were less public than male literary communities. ${ }^{30}$ During the early portion of the nineteenth century, even as professional opportunities in the public sphere expanded, writing was a means through which 
women could work safely in the private sphere of the home, "with only the name and product of the author being necessarily in the public domain." 31 This was somewhat true of Baillie, who got her start networking in a private literary salon. However, as her career progressed she made connections through her more public work as an editor and dramatist. Because Baillie's practice as a writer was so heavily networked-built upon social relationships but also extending out to editorial and theatrical collaborations later in her career - much of her most important work was produced in a more public fashion than has been hitherto acknowledged, and her career was less homogenous than might otherwise be assumed. Yet, important as her networked connectivity was, it was not yet considered the sort of work that led to canonical status. When the plays and volume editions of her works went out of print and out of fashion, her legacy was also largely forgotten, usually remembered only as a footnote in accounts of her broader, mixed-gender literary network, especially her relationship to the canonical novelist Sir Walter Scott. A networked analysis restores her status as a highly connected writer who was engaged with fellow women writers in substantial ways and who played an influential role in facilitating and interpreting their contributions to literary history.

\section{Geraldine Jewsbury (1812-80)}

Geraldine Jewsbury was born in Derbyshire twelve years after her sister Maria Jane Jewsbury (1800-33), whom she eventually followed into the publishing business. She ultimately surpassed her sister, publishing a large number of novels and journalistic pieces and later working as a publisher's reader. She also served as an editor and as a prolific critic and reviewer for The Athenaeum, for which it is believed she produced well over 2,000 reviews. ${ }^{32}$ Jewsbury faced significant trials early in life, with the death of both her mother and sister Maria before she had turned twenty-one. Left as the sole caretaker for her severely ill father, she experienced a 
profound crisis of faith. She discovered some comfort in the literary texts that Maria had left her, especially the works of Thomas Carlyle. After boldly writing him a letter regarding her interest in the themes of religious doubt in his work, she established a lifelong connection with him and, more importantly, with his wife, Jane Welsh Carlyle.

After corresponding with the Carlyles, Jewsbury was inspired, at the age of thirty-four, to begin publishing her own work. She began as a novelist, writing several books throughout the late 1840s and early 1850s, including Zoe: the History of Two Lives (1845), The Half Sisters (1848), and Marian Withers (1851), before transitioning to a career as a book reviewer for The Athenaeum and other journals. She also served as a reader for Bentley and Hurst \& Blackett. Her work as reader and reviewer, both of which tended to foster one-way connections, distinguishes her from Baillie, who, as previously demonstrated, was more likely to form mutual connections with those in her literary and theatrical orbit. Even though Jewsbury enjoyed a variety of reciprocal (blue-line) relationships, such as those with Jane Welsh Carlyle, Harriet Martineau, Mary Russell Mitford, and Elizabeth Barrett Browning, we can also see a greater influx of oneway (yellow-line) relationships. As a reader, Jewsbury evaluated and made recommendations on the work of writers such as Ouida, Mary Elizabeth Braddon, Rhoda Broughton, and Ellen Wood, who appear as smaller nodes on the network visualization. During her prolific reviewing career, Jewsbury also engaged with writers such as Charlotte Brontë, Ellen Mary Clerke, and Charlotte Yonge in one-sided connections - as was typical of the reviewing trade at mid-century. Jewsbury still engaged in networking as part of her personal relationships, through letters and visits (most notably with the Carlyles), as was the largely case for Joanna Baillie, but she was more likely to engage in strictly professional relationships with her fellow women writers. 
One possible reason for this connective shift during the mid-century, Shattock points out, was the "number of new and enabling public spaces for women writers [that] emerged from the 1840 s," which provided an increasing number of opportunities for networking among women writers. ${ }^{33}$ New opportunities in the publishing field - writing, editing, and reviewing - and the rise of the "celebrity author" in the latter half of the nineteenth century changed not only the literary marketplace and the publication practices of the period but also the ways in which authorship, especially for women, was defined. As Ellen Jordan notes, publishers began "abandoning the commitment to anonymity" and instead used "by the author of ..." or authors' initials, which allowed readers to identify their favorite writers. ${ }^{34}$ Later in the period, editors regularly advertised authorial identities when marketing their periodicals. Alexis Easley explains how this policy "made it increasingly difficult for women to engage in low-profile literary careers." 35 Barbara Onslow further observes that series like "Women Writers of the Century," published in the Englishwoman's Review, emphasized women's celebrity status. ${ }^{36}$ Thus, we are able to trace the roots of the shift from personal to blended personal and professional relationships for Jewsbury, as other authors, like Isabella Banks and Eliza Lynn Linton, were able to identify her reviews towards the latter half of her career.

This fundamental shift from the largely reciprocal composition of Baillie's network with fellow women writers to the heterogeneity of Jewsbury's professional relations follows Simon Potter's postulation that "from the mid-nineteenth century onward ... technological and commercial changes modified earlier patterns of interconnection and privileged particular links at the expense of others." ${ }^{37}$ Even though, as Orlando notes, Jewsbury held a reputation "among her contemporaries as a major influence on Victorian literature, her contributions as author and critic have faded into obscurity." 38 feminist scholars such as Elaine Showalter have attempted to 
rescue Jewsbury from obscurity by focusing on her novels. Yet focusing on Jewsbury's signed works of fiction does not do justice to the highly connected nature of her literary practice. Only through careful study of her behind-the-scenes, often anonymous, work in the publishing industry can we begin to assess her broader contribution to the history of women's writing.

\section{Margaret Ethel "Storm" Jameson (1891-1986)}

As a woman who memorably described herself as the "invisible aunt of English letters," Margaret Ethel "Storm" Jameson has, perhaps unsurprisingly, received scant scholarly attention. ${ }^{39}$ Jameson was born in Yorkshire in 1891 and was first published at the age of twentytwo in 1913. Married at a young age, she was acutely aware of the need to support her family as her husband finished his university studies and began teaching. The drive to work and to write propelled Jameson further into the publishing world than she at first thought possible. At the outset of her writing career, she lacked confidence in her abilities, noting that the "singular badness [of her first attempt] proves that I was not a born novelist. ${ }^{40}$ Nonetheless, Jameson continued writing fiction in order to make ends meet. She also began writing copy for an advertising agency, publishing reviews in periodicals such as the Egoist, and performing research work-all of which gave her the background and experience necessary to land a position as editor of the Commonwealth magazine and as the London representative of publisher Alfred A. Knopf. Jameson's furious work ethic, political activism, and strong literary output of novels dedicated to addressing the injustices of WWI led her to become the first female President of the English PEN (Poets, Essayists, and Novelists) Centre. Through PEN, she forged an everwidening network of connections to both male and female authors, including Rebecca West, Vera Brittain, Winifred Holtby, Naomi Mitchison, and Virginia Woolf (figure 4). 
Given her high degree of professional responsibility, it is unsurprising that Jameson's connections with fellow writers were numerous and diverse. As my visualization demonstrates, Jameson was linked to a high number of nodes, with an even mix of yellow one-sided connections and blue (reciprocal) connections. Jameson's work as a reviewer, like Jewsbury's, led to a proliferation of one-sided connections with fellow authors. However, by the beginning of the twentieth century, such reviews were more likely to be signed. Thus, even though the reviewer and the reviewed author might never meet, their names would be linked within the publishing world. For example, author Dorothy Richardson was recruited by a publisher to write a hybrid review and response piece to Jameson's essay "Bored Wives," a feminist critique of suburbia as an intellectual desert. Because Richardson's fame was nearly equal to Jameson's at the time, their names must have been linked, even though they did not interact socially or professionally. As a PEN organizer, she also worked closely with other authors through correspondence and in face-to-face reciprocal relationships. Her ability to serve in this latter role seems to have been a sign of the times-not only of women taking on more public roles but of assuming leadership during the war.

If, as Murphy and Gaipa suggest, "modernism's emergence" directly resulted from the "circulation and connectivity" of period authors and their literary associations, Jameson would seem to exemplify its success as a literary movement. ${ }^{41}$ So why is it that her self-described legacy is rendered all but invisible in literary history? One possible answer may be found in the nature of her connections with her contemporaries. As the president of the English PEN Centre, Jameson was a fully engaged and invested leader-organizing and running meetings, proposing and enacting policy change, and recruiting and retaining an organizational membership. Jameson was also fully invested in supporting the Allied efforts during both World Wars-speaking to 
politicians and to the public, writing and publishing pieces that fought back against Nazism and fascist ideology, and even fighting to raise funds for writers fleeing the terror and persecution of Europe, most especially during World War II. Jameson was abundantly engaged with and rooted in the specific issues of her time, which was reflected in her writing. Consequently, as Birkett and Briganti point out, when her first-generation modernist peers insisted that truly great literature must be taken "out of history and [cut] off from its political moorings," "Jameson was easily nudged out of a literary canon." ${ }^{\prime 2}$ Cast as an ephemeral novelist of a particular cultural moment, Jameson's name faded from literary history in favor of more well-known peers such as Virginia Woolf, whose novels, though still addressing the most pressing issue of the time- the war-more fully embodied modernism's ideals of timelessness and experimentation.

Though both Jameson and Woolf also engaged in various other forms of networked connectivity, such as reviewing, publishing, and writing about fellow women authors, Jameson's work was deemed too topical for lasting greatness, and therefore her other networked activity within print culture, though arguably just as significant as Woolf's, soon disappeared from visibility. Virago Press reprinted Jameson's most well-known novel, the autobiographical Journey to the North (1960), and second-wave feminism briefly rekindled scholarly curiosity in Jameson's life and work during the 1980s. Interest in Jameson's career and texts ultimately failed to gain traction, however, and she, like Baillie and Jewsbury, was cast into the shadow of her (largely male) contemporaries. Instead of being recognized as a central figure in nineteenthcentury women's literary print culture, all three women were reimagined as minor figures in the narratives and networks of canonical writers Sir Walter Scott, Thomas Carlyle and T. S. Eliot.

\section{Reading Broader Patterns in the Long Nineteenth Century}


In his 1927 text on literary evolution, Jurij Tynjanov proposes that "one cannot study literary phenomena outside of their interrelationships." 43 The connections forged between women of the long nineteenth century played a key role in their engagement with print culture, as their relationship dynamics evolved from personal, reciprocal associations earlier in the period towards more one-sided, professional capacities in the latter decades. Margaret Beetham suggests that "women were omnipresent from the beginning of the century as founders, editors and contributors" in the publishing industry—a theory clearly supported by analysis of the individual networks of Baillie, Jewsbury, and Jameson. ${ }^{44}$ Women writers were omnipresent in print culture throughout the nineteenth century but not always in a visibly public fashion, as seen both in the private networking that took place in salons and the domestic sphere and in the convention of anonymity that governed print culture for much of the period. However, as Shattock notes, with time "networking by women writers was conducted more in public than has been recognized," as is shown in the categorical shift tending toward personal, reciprocal relationships in the late eighteenth and early portions of the nineteenth centuries to an emphasis on professional associations in the late nineteenth and early twentieth centuries. ${ }^{45}$

Assembling my aggregated connectivity data revealed changes not only in network composition, but trends in network expansion as well. Joanna Baillie was linked to eleven other women writers in her time, Geraldine Jewsbury doubled that number at twenty-two, and Storm Jameson was slightly more connected at twenty-six women writers: a clear increase as the nineteenth century progressed. This increase, I argue, stemmed not only from the opportunities made possible by the expansion of print culture but also by women assuming more prominent positions in the publishing industry. By the latter half of the period, the publishing world became so flooded with aspiring writers that by necessity women were obliged to assume multiple 
roles-not just as novelists, playwrights, or poets, but as editors, reviewers, publishers' readers, and literary administrators. While this clearly afforded women more opportunities for connectivity, it also meant that they often took part in anonymous literary activity-influential roles that were nonetheless categorized as ephemeral in a broad view of literary history.

As Murphy and Gaipa note, "Visualizing large data sets can reveal structural transformations as they took shape" in a variety of literary eras. ${ }^{46}$ In graphing the network of 700 interconnected women writers, I was able to examine a temporal span long enough to see repeating patterns. As figure 1 illustrates, three distinct clusters of networks emerge from the overall figure, centered around similarly sized nodes, representing three individual writers distributed over three nearly equidistant periods of forty to fifty years. Each micro-network represents a cycle within the macro-level whole; Gephi is additionally able to measure the modularity of a set of network data, which means it is capable of measuring the "degree to which a network is divided into smaller communities. $" 47$ In graphing such a large span of time, this feature was particularly useful in foregrounding not only nodal hotspots of individual authorial connectivity but also distinguishing temporal connectivity pockets clustered around key women writers who flourished from 1750-1800, 1850-1900, and 1900-50. A new network appears to arise as one generation of writers gives way to another and as new women writers become central nodes within women's writing communities. These distinct, clustered pockets reveal a repeating, roughly fifty-year cycle of densely connected, intertwined nodes, each centered around a key woman writer.

As Moretti observes, "cycles constitute temporary structures with the historical flow" of the network graph, cycles that point us to a generalized time period or literary movement, but the very nature of the network graphs shows us that the interconnections that occur between authors 
of such movements often transcend the movements themselves. ${ }^{48}$ Romantic, Victorian, or Modernist women writers cannot simply be clustered together and made to fit into predetermined contextual boxes. Though a surface reading of my macro-network graph suggests repeating patterns of homogenous authorial clusters appeared at regular intervals centered around certain women in specified time periods, closer inspection of the individual case studies reveals the cross-temporal nature of the connections between these women, suggesting much more complex relationships than have hitherto been understood. They simultaneously cultivated connectivity with one another in the present and wrote retroactively about their literary foremothers. Not only were they involved in documenting women writers' uniquely gendered history within the publishing industry, but many female authors also engaged in analyzing and critiquing the way that the works of these same women writers had entered, existed, and endured in the marketplace alongside those of their dominant male peers.

In light of its temporal entanglement with both past and present, network analysis, I contend, should be conceived of as a tool for investigating multiple points of origin and entry into the study of writers in the nineteenth century rather than as the end-structure proof of preexistent theories. Dallas Liddle warns that "long-standing priorities within our scholarly culture will encourage scholars who rely on existing research to continue thinking in these wellestablished terms." 49 Networks open lines of inquiry, rather than closing off previously held assumptions or hypotheses. My study aims to expand the canon to include, or at least consider, the kinds of important roles women played both on the literary public stage and behind the scenes. Perhaps, given their capacity for influencing fellow women writers and reclaiming female authors of the past, networked relationships are a better measure of any given writer's influence in literary history than their published works of imaginative literature. ${ }^{50}$ This idea of 
the importance of influence is complex, referencing matters of literary style and output, celebrity, connectivity, opportunity, critical acclaim, etc. But, as Alison Chapman explores in her chapter of The Cambridge Companion to Victorian Women's Writing, bids for canonicity by women writers were made on a variety of literary and literary-adjacent claims, from saintly genius in the case of Christina Rosetti to imaginative virtue and literary style for Charlotte Brontë to intellectual power and paragonic leadership for George Eliot. ${ }^{51}$ If nothing else, my study both creates a space for academic conversation surrounding and suggests a methodology for considering the concepts of connectivity and influence as one such viable claim for canonicity.

\section{Archival Gaps and Silences: The Orlando Project}

In examining the lives and networks of Baillie, Jewsbury, and Jameson, my goal was to illustrate the way that women's networks evolved structurally and temporally during the long nineteenth century. Of course, the validity of network analysis in defining both presence and absence in women's literary history depends on the quality of the source data used as a foundation for research-in this case, the Orlando Project database. As Lauren Klein notes, we must think of the digital archive "not as a neutral repository of knowledge, but instead as a tool for exposing the limits of our knowledge." 52 As scholars, we must consider the "epistemological assumptions" built into our use and visualization of data and "engage in a critical description" of such tools when putting them into practical use. ${ }^{53}$

Just as I have mined the digital material of the Orlando database, I must also interrogate the project's gaps and silences. Given the stake I have in the data's validity, "it is vital," as Paul Fyfe argues, to "account for its history." 54 The Orlando Project database is a relatively new resource in digital scholarship that is rooted in work by editors Virginia Blain, Patricia Clements, and Isobel Grundy in their volume The Feminist Companion to Literature in English: Women 
Writers from the Middle Ages to the Present. The three editors initially compiled entries on women authors for a reference book on women's writing across several eras and aesthetic movements. By the end of that the project, they found that the content they collected had grown too large to be feasibly contained in a hard-copy volume. In 2006, the latter two editors, along with scholar Susan Brown, turned their attention to creating a digital project on feminist literary history. ${ }^{55}$ The first iteration of the web archive launched in 2010 incorporated entries on just over 1,000 British women writers-with British male writers and international women writers occasionally included at the editors' discretion. In 2013, the database underwent another major expansion, bringing the total number of writers listed to 1,325 entries. ${ }^{56}$ Yet, even with this fairly large cross-sectional sample of women writers, the archive remains (and will perennially be) incomplete. "Archival silence," Klein reminds us, "remains difficult to address." 57 The nearly 700 women writers I mined from the Orlando Project database do not begin to approximate the actual number of women writers who published during the long nineteenth century, which numbered in the tens if not hundreds of thousands. Thus, while the Orlando sample is large compared to the number of authors usually covered in reference books or in scholarship on women's authorship, it is a small selection that perhaps reflects the particular knowledge and interests of the editors who created it.

Probing the data reveals gaps at both the micro- and macro-level. For the former, within individual author listings, I grappled with constraints in collecting writer connectivity data created by what the editors-and the postdoctoral fellows and research assistants they directedopted to include in the "Life and Writing" summaries, as well as under the "Friends, Associates" and "Family" tags. In their introduction, the editors describe their methodology and reasoning:

Entry length is governed by a range of factors. The first is the historical importance, as we see it, of the writer. Authors with full entries have been picked for historical 
or literary interest (or both); a few treated only briefly in timeline material are candidates for full entries in some approaching update; a few (mostly from early periods) have no "Life" screen because information about them is so sparse. ${ }^{58}$

Michel Rolph-Troulliot describes this process as "the moment of fact assembly," during which archival silence becomes encoded. ${ }^{59}$ The privileging of certain authors over others, as reflected in the degrees of completeness for individual entries, clearly shows that not only information availability but also commercial concerns, scholarly interest, and marketability, was taken into account. Given that the Orlando Project relies on paid subscriptions to be financially viable, its selection bias is understandable, yet this selectivity also makes it difficult to judge the influential status of writers within print culture in an unbiased and unfiltered way. On the macro-level, the question of connectivity itself arose within the digital archive. The difficulties I encountered when attempting to collect my data on women writers' relationships and associations with one another reinforces what Emily Midorikawa and Emma Claire Sweeney call the "mythologizing" of female authors "as solitary eccentrics or isolated geniuses." 60 Archives necessarily isolate and detach a subject or individual component in order to present information, but this necessarily removes individuals or texts from their connections and contexts. It is the work of the scholar, of course, to act as the mediator who mines the subject/component of a database or archive and makes the connections visible to readers in order to highlight the importance of a specific author or text-but the question remains, how do we perform this work without privileging canonical authors over others? How (if at all) can we situate women writers within the communities of their time in an unbiased way?

\section{Conclusion}

Approaching archival data and its practical usages from a macroanalytic standpoint allows scholars to pose academic questions in a way that at first seems relatively free from the 
conventional biases that inform literary study. Yet if the information included in the database is itself informed by what we already know about authors from conventional research-with canonical women writers' lives and works being much more well-known than those of their noncanonical sisters-then how can we ever hope to achieve an unbiased vision? As Paul Fyfe puts it, "How do you discover things you did not know to look for?"61 Or, as Barbara Onslow notes, "If we mine only for ' $\mathrm{x}$ '... we are getting a very partial intellectual picture." ${ }^{62}$ Perhaps we can only hope for partial truths when utilizing any data set. Nevertheless, it is a valuable exercise to try to gain a sense of distance from our usual objects of analysis and experiment with methods that defamiliarize them in engaging ways.

By utilizing network analysis tools and data visualization, we are not only able to see what is present-but also what is not. Visualization transforms data so that we can examine it in context with other sets of data points and thus consider it in relative terms. In analyzing connectivity data for women writers of the long nineteenth century and discovering surprisingly important nodes within these networks-such as Joanna Baillie, Geraldine Jewsbury, and Storm Jameson-we can begin to redefine what constitutes a writer's influence in literary history. We are invited to confront our own culpability in overlooking certain writers in favor of others. As Lauren Klein notes, it is "this image of absence [that] challenges us as critics to make the unrecorded stories that we detect-those that we might otherwise consign to the past--instead expand with motion and meaning." ${ }^{63}$ Repeated scholarly attention to a select group of women writers has not only solidified their place within the canon but also reinforced "readers' familiarity with these authors," underscoring "their perceived worth and significance." engaging with network analysis on a macroanalytic scale rather than taking the canonical individual or coterie as a starting point, I hope to raise fresh questions about women's experience 
in the literary marketplace — and about the archives that claim to represent them. A distant reading approach, followed by the close reading of biographical data, promises to dislodge our preconceptions and stereotypes about women's writing, canon-formation, and the idea of influence and importance in literary history.

\section{NOTES}

${ }^{1}$ For example, Natalie Houston's ongoing map of the textual relationships between Victorian poets and publishers ("Toward a Computational Analysis of Victorian Poetics") or Anne DeWitt's recent data visualization study concerning reviews and the Victorian theological novel ("Advances in the Visualization of Data: The Network of Genre in the Victorian Periodical Press.").

${ }^{2}$ Easley, "Introduction," 112-13.

${ }^{3}$ Shattock, "Professional Networks," 134.

${ }^{4}$ See for example, Chauncey Brewster Tinker, The Salon and English Letters: Chapters on the Interrelations of Literature and Society in the Age of Johnson, 30-41; Alison Chapman, Networking the Nation: British and American Women's Poetry and Italy, 1840-1870, 3-18; and Susanna Schmid, British Literary Salons of the Late Eighteenth and Early Nineteenth Centuries. ${ }^{5}$ Van Remoortel, "Agents of Change," n.p.

${ }^{6}$ Booth, "Collective Biographies of Women," n.p.

${ }^{7}$ See Brake, “'Time's Turbulence': Mapping Journalism Networks”; Hensley, "Network:

Andrew Lang and the Distributed Agencies of Literary Production"; Murphy and Gaipa, "You Might Also Like...: Magazine Networks and Modernist Tastemaking in the Dora Marsden Magazine"; Shattock, "Professional Networking, Masculine and Feminine"; So and Long, "Network Analysis and the Sociology of Modernism." 
${ }^{8}$ Moretti, Distant Reading, 66-67.

${ }^{9}$ Jockers, Macroanalysis, 26.

${ }^{10}$ Murphy, "Introduction," iv.

${ }^{11}$ Murphy and Gaipa, "You Might Also Like," 52 (my emphasis); Brake, "Time's Turbulence," 116 (my emphasis).

${ }^{12}$ Hensley, "Network," 377.

${ }^{13}$ Potter, "Webs, Networks, and Systems," 622.

${ }^{14}$ Jockers, Macroanalysis, 29.

${ }^{15}$ Ibid., 32.

${ }^{16}$ Felski, "“Context Stinks!,"” 574, 573.

${ }^{17}$ Ibid., 574-75.

${ }^{18}$ The first component is, of course, intrinsic to the scope of my analysis. The second was included so that I would be assured of mapping connections between women writers specifically. Texts published pseudonymously or anonymously would not be able to be attributed with absolute surety to a female author, and so certain authors could not be entertained for this study. ${ }^{19}$ Examples of previous studies focused on group networks include Patrick Leary's examination of the Punch brotherhood, or P.D. Edwards' exploration of Dickens and his circle of writers.

${ }^{20}$ Latour, Reassembling the Social, 8; emphasis in original.

${ }^{21}$ Ibid.

${ }^{22}$ Van Remoortel, "Who Do You Think They Were?" 131.

${ }^{23}$ Murphy and Gaipa, "You Might Also Like," 53. 
${ }^{24}$ Indeed, as Barbara Onslow laments, the names of writers such as Geraldine Jewsbury are familiar only to "scholars specializing in nineteenth-century feminism," and not to general readers. (Women of the Press, 1.)

${ }^{25}$ Watt, Rise of the Novel, 45, 290.

${ }^{26}$ Brown, Clements, and Grundy, "Joanna Baillie: Life \& Writing."

${ }^{27}$ Martineau, Autobiography, 358.

${ }^{28}$ One useful feature that Gephi offers is to create a personalized, 3D graph for each author, showing their connections on an individual scale to other writers in the larger whole, as I have provided here for Baillie, Jewsbury, and Jameson.

${ }^{29}$ McLean, Thomas. "Donation and Collaboration: Joanna Baillie's A Collection of Poems, Chiefly Manuscript, and From Living Authors, April 1823."

${ }^{30}$ Potter, "Webs, Networks, and Systems," 634.

${ }^{31}$ Thompson, "Women, Work, and Politics," 69.

${ }^{32}$ The exact number of Jameson's reviews for the Athenaeum is unknown since many of the periodical's reviews remain unattributed due to the fact that, as Joanne Shattock points out, "Anonymity remained entrenched in the reviewing of the 1850s." ("The 'Orbit' of the Feminine Critic," n.p.)

${ }^{33}$ Shattock, "Researching periodical networks," 61-62.

${ }^{34}$ Jordan, "The Magazine for the Young," n.p.

${ }^{35}$ Easley, First-Person Anonymous, 5.

${ }^{36}$ Onslow, Women of the Press, 2.

${ }^{37}$ Potter, "Webs, Networks, and Systems," 634.

${ }^{38}$ Brown, Clements, and Grundy, "Geraldine Jewsbury." 
${ }^{39}$ Maslen, Life in the Writings, 401.

${ }^{40}$ Jameson, quoted in Birkett and Briganti, Margaret Storm Jameson, 3.

${ }^{41}$ Murphy and Gaipa, "You Might Also Like," 31.

${ }^{42}$ Birkett and Briganti, Margaret Storm Jameson, 10.

${ }^{43}$ Tynjanov, quoted in Jockers, Macroanalysis, 9.

${ }^{44}$ Jordan, "The Magazine for the Young," n.p. For further detail see Beetham, A Magazine of Her Own?, 17-44.

${ }^{45}$ Shattock, "Professional Networking," 137.

${ }^{46}$ Murphy and Gaipa, "You Might Also Like," 33.

${ }^{47}$ Ibid., 52.

${ }^{48}$ Moretti, "Graphs, Maps, and Trees,” 76.

${ }^{49}$ Liddle, "Genre," 395.

${ }^{50}$ Murphy, "Introduction," iv.

${ }^{51}$ See Chapman, "Achieving fame and canonicity," 78-83.

${ }^{52}$ Klein, "Image of Absence," 684.

${ }^{53}$ Drucker, "Graphical Approaches," 248.

${ }^{54}$ Fyfe, "Archaeology of Victorian Newspapers," 552.

${ }^{55}$ Brown, Clements, and Grundy currently serve as the three project editors for the site and oversee its content development, with each taking responsibility for a section of history-Brown oversaw women's writing from 1820-1890, Clements works with writing from 1880-present, and Grundy manages writing from the "beginning" to around 1830. The archive also lists seven coinvestigators, fourteen technical personnel, eight postdoctoral fellows, one hundred and six 
research assistants, seven administrators, and two external consultants, who have all served in various capacities to build and launch the Orlando Project into its current digital form.

${ }^{56}$ The database continues to update its records on a biannual basis, but the additions are fairly minor (typically anywhere from 10-25 new writers are added) and smaller revisions to existing writers' bibliographies, tags, links, and biographies also occur during this time.

${ }^{57}$ Klein, "Image of Absence," 662.

${ }^{58}$ Brown, Clements, and Grundy, "Literary History with a Difference," n.p.

${ }^{59}$ Rolph-Troulliot, quoted in Klein, "Image of Absence," 663.

${ }^{60}$ Midorikawa and Sweeney, Secret Sisterhood, 13.

${ }^{61}$ Fyfe, "Technologies of Serendipity," 263.

${ }^{62}$ Onslow, Women of the Press, 3.

${ }^{63}$ Klein, "Image of Absence," 675.

${ }^{64}$ Murphy and Gaipa, "You Might Also Like," 42. 


\section{BIBLIOGRAPHY}

Beetham, Margaret. A Magazine of Her Own? Domesticity and Desire in the Woman's Magazine. London: Routledge, 1996.

Bentkowska-Kafel, Anna, Hugh Denard, and Drew Baker, eds. Paradata and Transparency in Virtual Heritage (Digital Research in the Arts and Humanities). New York: Routledge,
2012.

Best, Stephen, and Sharon Marcus. "Surface Reading: An Introduction." Representations 108, no. 1 (Fall 2009): 1-21.

Birkett, Jennifer, and Chiara Briganti, eds. Margaret Storm Jameson: Writing in Dialogue. Newcastle: Cambridge Scholars Pub., 2007.

Booth, Alison. "Collective Biographies of Women." Part of NINES, and produced by The Scholars' Lab, University of Virginia Library. Accessed March 15, 2018. http://womensbios.lib.virginia.edu/.

Brake, Laurel. "“Time's Turbulence': Mapping Journalism Networks." Victorian Periodicals Review 44, no.2 (Summer 2011): 115-27.

Brown, Susan, Patricia Clements, and Isobel Grundy, eds. "Joanna Baillie." Orlando: Women's Writing in the British Isles from the Beginnings to the Present. Cambridge: Cambridge University Press Online, 2006. http://orlando.cambridge.org/.

Brown, Susan, Patricia Clements, and Isobel Grundy, eds. "Geraldine Jewsbury." Orlando: Women's Writing in the British Isles from the Beginnings to the Present. Cambridge: Cambridge University Press Online, 2006. http://orlando.cambridge.org/.

Brown, Susan, Patricia Clements, and Isobel Grundy, eds. "Storm Jameson." Orlando: Women's Writing in the British Isles from the Beginnings to the Present. Cambridge: Cambridge University Press Online, 2006. http://orlando.cambridge.org/.

Burrows, John Frederick. Computation into Criticism: A study of Jane Austen's novels and an experiment in method. Cotswolds: Clarendon Press, 1987.

DeWitt, Anne. "Advances in the Visualization of Data: The Network of Genre in the Victorian Periodical Press." Victorian Periodicals Review 48, no. 2 (Summer 2015): 161-82.

Drucker, Johanna. "Graphical Approaches to Digital Humanities." In A New Companion to Digital Humanities, $2^{\text {nd }}$ edition, edited by Susan, Schreibman, Ray Siemens, and John Unsworth, 238-50. Hoboken: John Wiley \& Sons, Inc., 2016.

Easley, Alexis. "Introduction to the Special Issue: Victorian Networks and the Periodical Press." Victorian Periodicals Review 44, no.2 (Summer 2011): 111-14. 

First-Person Anonymous: Women Writers and Victorian Print Media, 1830-1870.
Farmham: Ashgate, 1994.

Felski, Rita. "Context Stinks!" New Literary History 42, no. 4 (Autumn 2011): 573-91.

Fyfe, Paul. "An Archaeology of Victorian Newspapers." Victorian Periodicals Review 49, no. 4 (Winter 2016): 546-77.

"Technologies of Serendipity." Victorian Periodicals Review 48, no. 2 (Summer 2015):

Hensley, Nathan K. "Network: Andrew Lang and the Distributed Agencies of Literary Production." Victorian Periodicals Review 48, no. 3 (Fall 2015): 359-82.

Houston, Natalie. "Toward a Computational Analysis of Victorian Poetics." Victorian Studies 56, no. 3 (Spring 2014): 498-510.

Jockers, Matthew L. Macroanalysis: Digital Methods \& Literary History. Champaign: University of Illinois Press, 2013.

Jordan, Ellen. "The Magazine for the Young: Female Literary Networks and the Development of the Literary Magazine for Children." Nineteenth-Century Gender Studies 13, no. 3 (Winter 2017). http://www.ncgsjournal.com/issue 133/jordan.htm.

Klein, Lauren F. "The Image of Absence: Archival Silence, Data Visualization, and James Hemings." American Literature 85, no. 4 (December 2013): 661-88.

Latour, Bruno. Reassembling the Social: An Introduction to Actor-Network-Theory. New York: Oxford University Press, 2005.

- "Networks, Societies, Spheres: Reflections of an Actor-Network-Theorist." International Journal of Communication 5 (2011): 799-800.

Liddle, Dallas. "Genre: 'Distant Reading' and the Goals of Periodicals." Victorian Periodicals Review 48, no. 3 (Fall 2015): 383-402.

Martineau, Harriet. Autobiography. 2 vols. Boston: James R. Osgood and Co., 1855

Maslen, Elizabeth. Life in the Writings of Storm Jameson: A Biography. Evanston: Northwestern University Press, 2014. 
McLean, Thomas. "Donation and Collaboration: Joanna Baillie's $A$ Collection of Poems, Chiefly Manuscript, and From Living Authors, April 1823." Branch Collective. Accessed March 28, 2018. http://www.branchcollective.org/?ps_articles=thomas-mclean-donation-and-collaborationjoanna-baillies-a-collection-of-poems-chiefly-manuscript-and-from-living-authors-april-1823.

Midorikawa, Emily, and Emma Claire Sweeney. A Secret Sisterhood: The hidden friendships of Austen, Brontë, Eliot and Woolf. London: Quarto Publishing, 2017.

Moretti, Franco. "Graphs, Maps, Trees.” New Left Review 24 (Nov-Dec 2003): 67-93.

- Distant Reading. New York: Verso, 2013.

Murphy, J. Stephen. "Introduction: Visualizing Periodical Networks." The Journal of Modern Periodical Studies 5, no. 1 (2014): iii-xv.

Murphy, J. Stephen, and Mark Gaipa. "You Might Also Like...: Magazine Networks and Modernist Tastemaking in the Dora Marsden Magazine." The Journal of Modern Periodical Studies 5, no. 1 (2014): 27-68.

Onslow, Barbara. Women of the Press in Nineteenth-Century Britain. Basingstoke: Macmillan, 2000.

Peterson, Linda H. Becoming a Woman of Letters: Myths of Authorship and Facts of the Victorian Market. Princeton: Princeton University Press, 2009

Potter, Simon J. "Webs, Networks, and Systems: Globalization and the Mass Media in the Nineteenth- and Twentieth-Century British Empire." Journal of British Studies 46, no. 3 (July 2007): 621-46.

Shattock, Joanne. "The 'Orbit' of the Feminine Critic: Gaskell and Eliot." Nineteenth-Century Gender Studies 6, no. 2 (Summer 2010).

http://www.ncgsjournal.com/issue62/shattock.htm. . "Professional Networking, Masculine and Feminine." Victorian Periodicals Review 44,
no. 2 (Summer 2011): 128-40.

- "Researching periodical networks: William and Mary Howitt." In Researching the Nineteenth-Century Periodical Press: Case Studies, edited by Alexis Easley, Andrew King, and John Morton, 60-73. Routledge: London, 2017.

Smith, Barbara Herrnstein. "What Was 'Close Reading'?: A Century Method in Literary Studies." Minnesota Review 87 (2016): 57-75.

So, Richard Jean, and Hoyt Long. "Network Analysis and the Sociology of Modernism." boundary 240 , no. 2, (2013): 147-182. 
Thompson, Dorothy. "Women, Work, and Politics in Nineteenth-Century England: the Problem of Authority." In Equal or Different: Women's Politics 1800-1914, edited by Jane Rendall, 37-69. Oxford: Blackwell, 1987.

Van Remoortel, Marianne. "Agents of Change: Women Editors and Socio-Cultural Transformation in Europe, 1710-1920." Funded by the European Research Council, housed at the Department of Literary Studies, Ghent University, Belgium. Accessed March 1, 2018. http://www.wechanged.ugent.be/.

—. "Who Do You Think They Were?: What genealogy databases can do for Victorian periodical studies." In Researching the Nineteenth-Century Periodical Press: Case Studies, edited by Alexis Easley, Andrew King, and John Morton, 131-44. Routledge:
London, 2017.

Watt, Ian. Rise of the Novel. $2^{\text {nd }}$ edition. Berkley: University of California Press, 2001. 


\section{FIGURES}

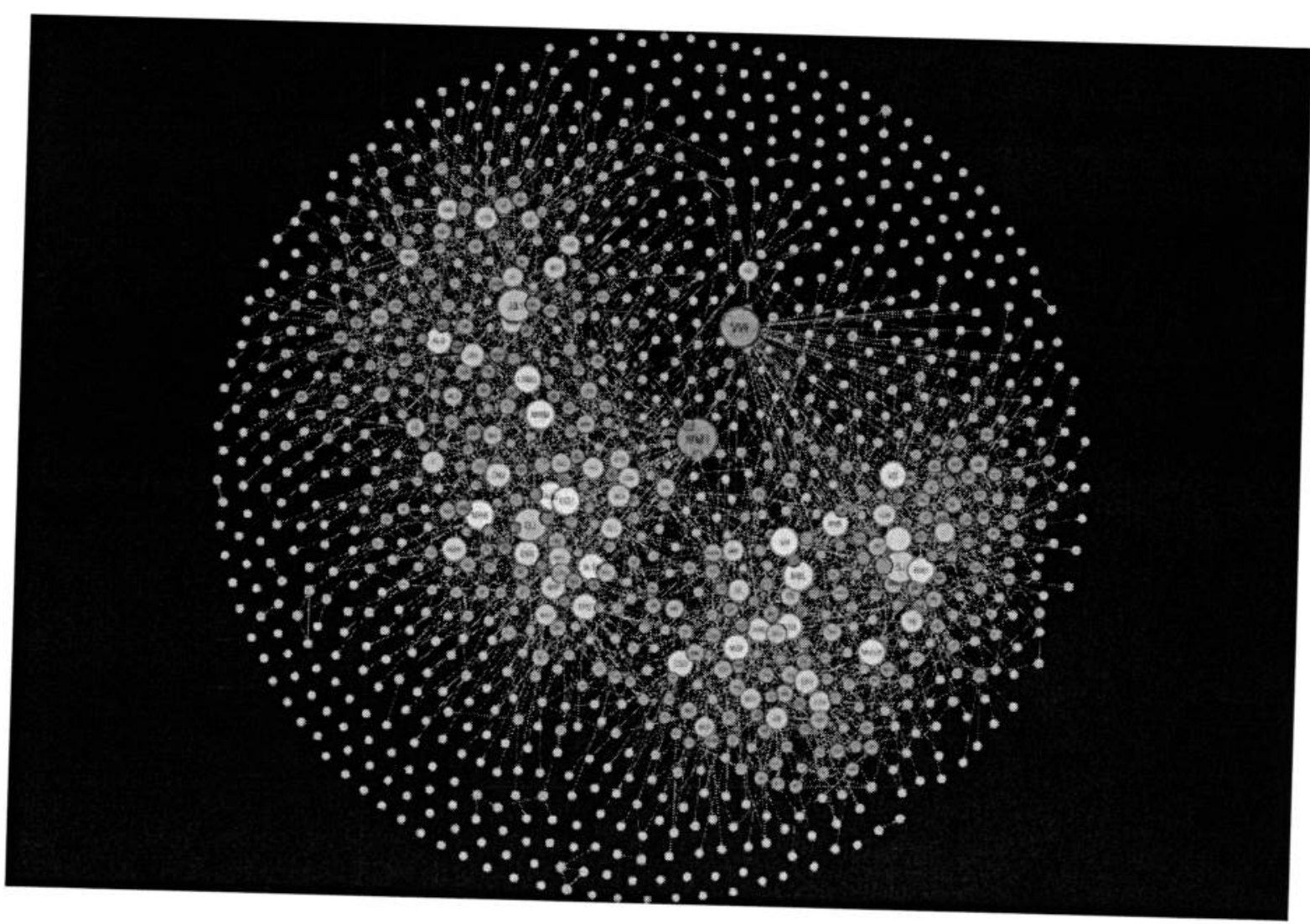

Figure 1. Network of associations among British women writers during the long nineteenth
century. 


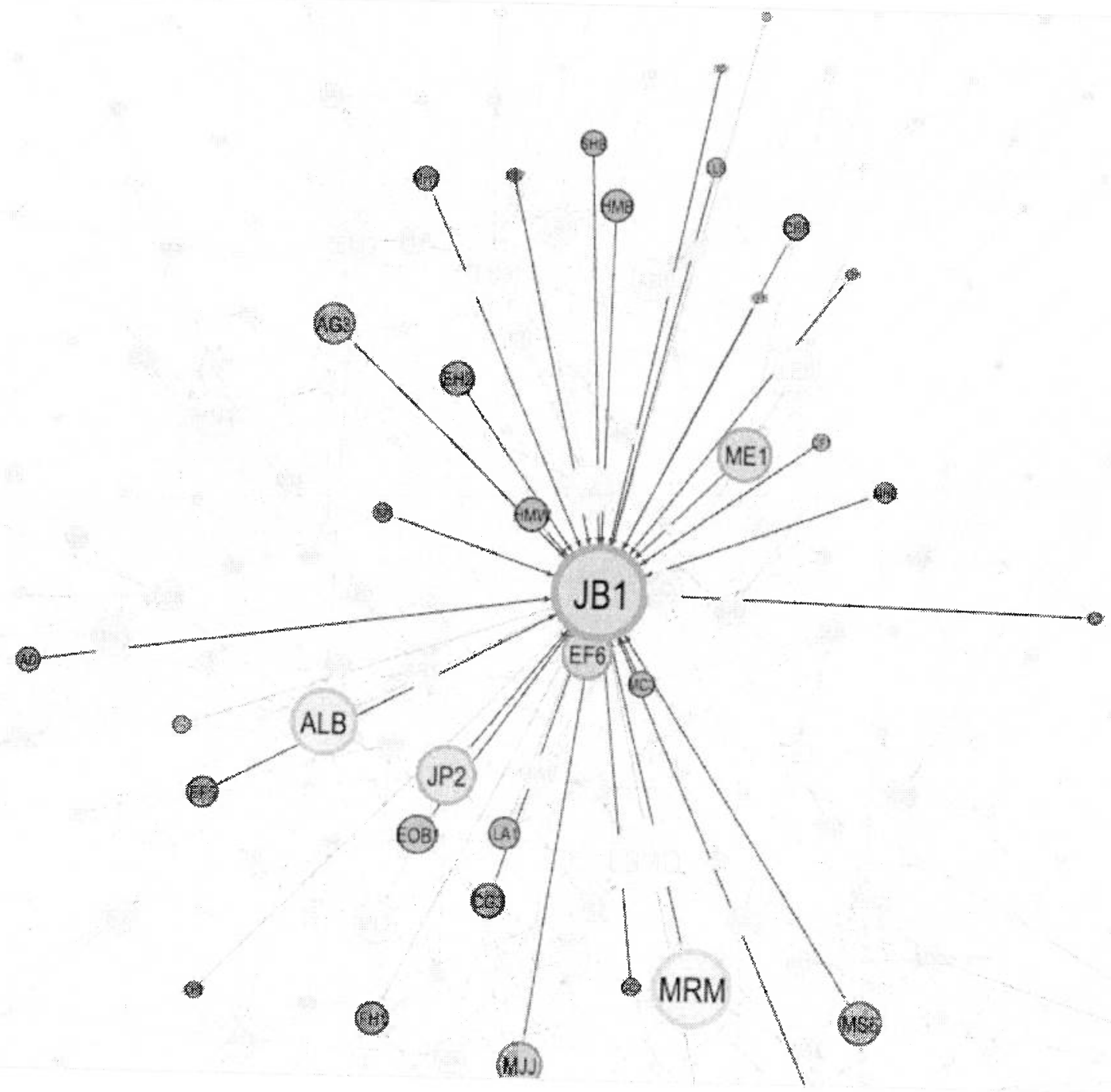

Figure 2. Close-up of the community of women writers surrounding Joanna Baillie (1762-1851). 


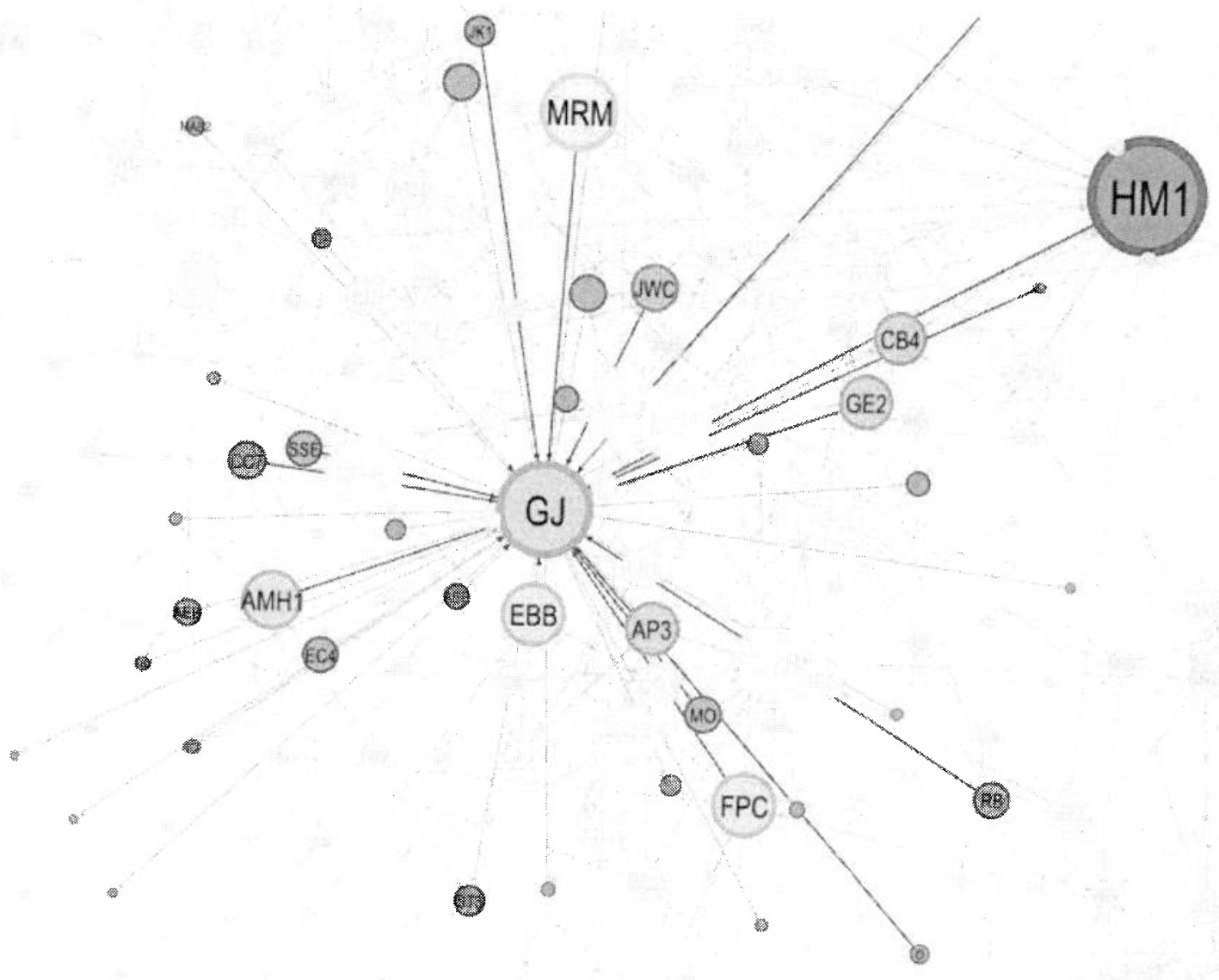
Figure 3. Close-up of the community of women writers surrounding Geraldine Jewsbury (1812-
80 ). 


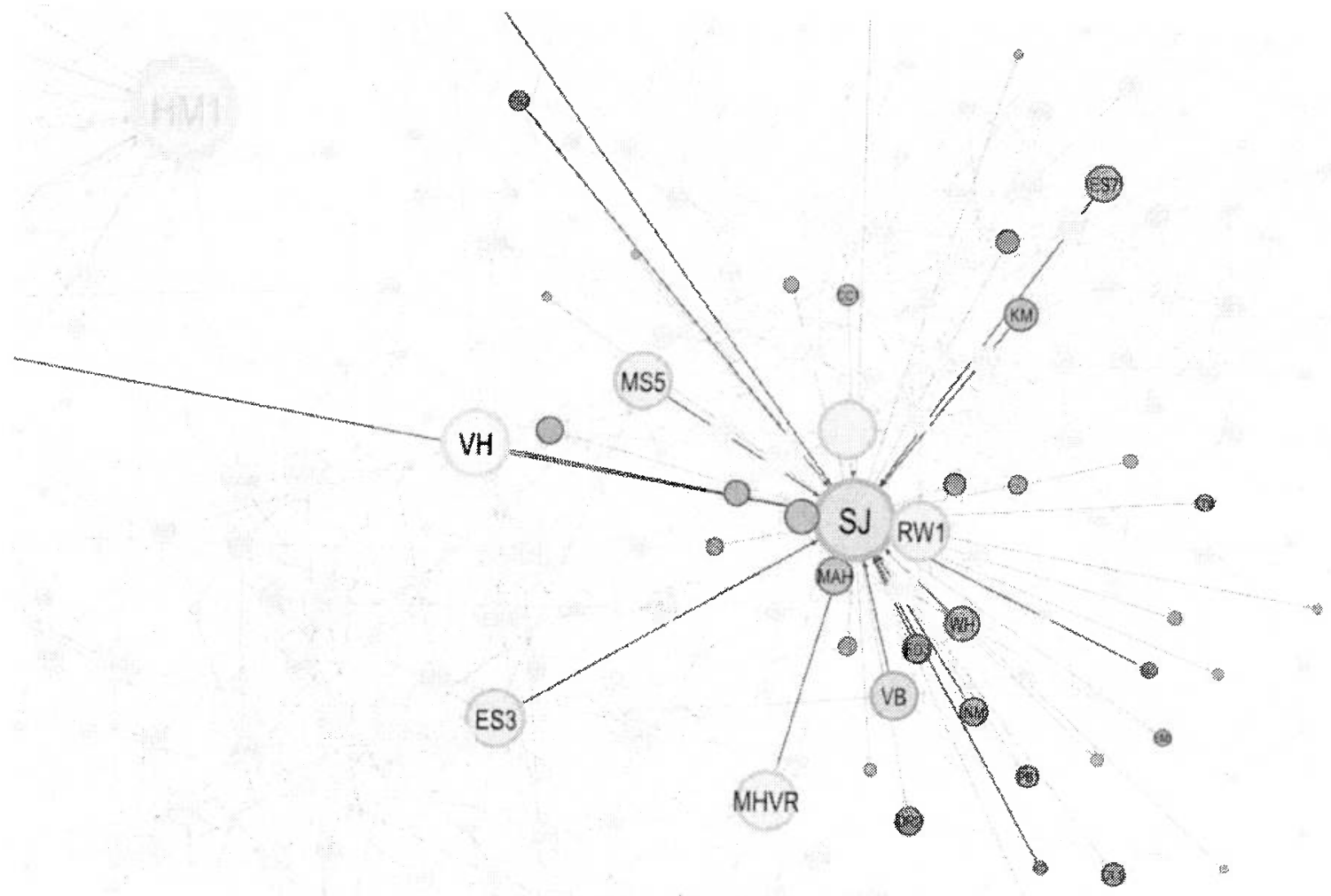

Figure 4. Close-up of the community of women writers surrounding Margaret "Storm" Jameson (1891-1986). 